\title{
A single nucleotide polymorphism in the promoter region of river buffalo stearoyl CoA desaturase gene $(S C D)$ is associated with milk yield
}

\author{
Alfredo Pauciullo ${ }^{*}$, Gianfranco Cosenza ${ }^{*}$, Roberto Steri ${ }^{2}$, Angelo Coletta ${ }^{3}$, Antonio La Battaglia ${ }^{4}$, \\ Dino Di Berardino ${ }^{1}$, Nicolò P P Macciotta ${ }^{2}$ and Luigi Ramunno ${ }^{1}$ \\ ${ }^{1}$ Department of Soil, Plant, Environment and Animal Production Science, University of Naples 'Federico II', Portici (NA), Italy \\ ${ }^{2}$ Department of Agricultural Sciences, University of Sassari, Sassari, Italy \\ ${ }^{3}$ Associazione Nazionale Allevatori Specie Bufalina, Località Centurano, Caserta, Italy \\ ${ }^{4}$ Comunità Montana Alto Agri, Villa D'Agri di Marsicovetere (PZ), Italy
}

Received 27 January 2012; accepted for publication 11 May 2012; first published online 20 September 2012

\begin{abstract}
An association study between the milk yield trait and the stearoyl-CoA desaturase (SCD) polymorphism (g.133A $>$ C) in Italian Mediterranean river buffalo was carried out. A full characterization of the river buffalo SCD promoter region was presented. Genotyping information was provided and a quick method for allelic discrimination was developed. The frequency of the $C$ allele was $0 \cdot 16$. Test-day (TD) records (43510) of milk production belonging to 226 lactations of 169 buffalo cows were analysed with a mixed linear model in order to estimate the effect of g.133A $>C$ genotype, as well as the effect of parity and calving season. The $S C D$ genotype was significantly associated with milk yield $(P=0 \cdot 02)$. The genotype AC showed an over-dominance effect with an average daily milk yield approximately $2 \mathrm{~kg} / \mathrm{d}$ higher than CC buffaloes. Such a difference represents about $28 \%$ more milk/d. The effect of the genotype was constant across lactation stages. The contribution of $S C D$ genotype $\left(r_{S C D}^{2}\right)$ to the total phenotypic variance in milk yield was equal to $0 \cdot 12$. This report is among the first indications of genetic association between a trait of economic importance in river buffalo. Although such results need to be confirmed with large-scale studies in the same and other buffalo populations, they might offer useful indications for the application of MAS programmes in river buffalo and in the future they might be of great economic interest for the river buffalo dairy industry.
\end{abstract}

Keywords: Mediterranean river buffalo, stearoyl CoA desaturase gene (SCD), milk yield, marker assisted selection.

The buffalo is a relatively young species, domesticated approximately 5000 years ago. The little exchange of buffaloes among countries allowed a good differentiation among the known breeds, thus nowadays each population has maintained its own phenotypic traits and performances (Borghese \& Mazzi, 2005). A long period of isolation and the lack of crossbreeding allowed an evident morpho-functional differentiation of the Mediterranean type, which has been recognized as 'Mediterranean Italian' breed since 2000 (D. M. 201992 - 5/7/2000).

The Italian buffalo population has increased of $53.5 \%$ in the decade 1999-2009 (http://www.aia.it). The reason for

*For correspondence; e-mail: apauciul@unina.it; giacosen@unina. it this trend lies in the growing interest of farmers in buffalo milk production (not subject to EU milk quotas), and the increasing market demand for mozzarella PDO (Protected Denomination of Origin-Reg. EC 510/2006) cheese. Such an increase of economic importance and size of the dairy Buffalo industry was followed by a limited improvement of the production level of the animals. Average milk yield per buffalo cow is $2180 \pm 597 \mathrm{~kg}$ in $270 \mathrm{~d}$ of lactation (it was $2140 \mathrm{~kg}$ in the year 2000) with 8.45 and $4.59 \%$ of fat and protein contents respectively (AIA, 2010).

Gene polymorphisms significantly associated with milk production traits may provide useful indications for identifying selection candidates with high genetic merit. In this regard, a single nucleotide polymorphism (SNP) (EMBL acc. no. FM876222: g.133A $>$ C) recently reported in the promoter region of the river buffalo stearoyl-CoA 
desaturase (SCD) gene (Pauciullo et al. 2010) is particularly interesting.

Stearoyl-CoA desaturase is a microsomal enzyme which plays a key role in fatty acid metabolism. It is also known as delta-9-desaturase because it catalyses the introduction of the first cis-double bond in the $\Delta 9$ position in a large spectrum of fatty acyl-CoA substrates (Ntambi, 1999). The stearoyl-CoA desaturase (SCD) locus has been suggested as a candidate gene affecting milk fatty acid (FA) profile (Gautier et al. 2006). In river buffalo, the g.133A > C SNP creates a new consensus site for the SP1 binding site and a preliminary association study with the milk FA content showed a significant effect on the desaturation index (Pauciullo et al. 2010). In sheep, no significant associations have been reported (García-Fernández et al. 2010), even though this gene is a strong positional and functional candidate for a quantitative trait locus (QTL) detected on chromosome 22 for the conjugated linoleic acid (CLA)/vaccenic ratio in milk (Carta et al. 2008). Associations between polymorphisms in SCD gene and the FA composition of milk have been reported in cattle (Mele et al. 2007; Moioli et al. 2007); and, recently a polymorphism at bovine $S C D$ locus has also been associated with daily milk yield with a constant effect of the genotype across lactation stages (Macciotta et al. 2008). Therefore, SCD locus has been proposed in geneassisted selection programmes for the improvement of milk production traits in dairy cattle (Macciotta et al. 2008).

The aim of this study was to investigate the occurrence of the above mentioned polymorphism at the SCD locus in the Italian Mediterranean river buffalo and to test possible associations with milk yield.

\section{Materials and Methods}

\section{Sample collection and nucleic acid isolation}

A total of 322 buffaloes from different commercial herds located in two provinces (Salerno and Caserta) of the Campania region (Southern Italy) were considered in the study. Most of the farmed buffaloes of the country are in this region of Italy.

Biological samples of these animals were used to extract DNA from blood, using the procedure described by Gossens \& Kan (1981).

DNA concentration and $\mathrm{OD}_{260 / 280}$ ratio of the samples were measured with the Nanodrop ND-2000C Spectrophotometer (Thermo Scientific).

\section{PCR conditions and genotyping by TaqI PCR-RFLP}

PCR reaction mixture and thermal conditions for the amplification of the DNA fragment spanning from $-593 \mathrm{bp}$ of $5^{\prime}$ flanking region to $+159 \mathrm{bp}$ of exon 1 (752 bp) of the river buffalo SCD gene were accomplished by using the following primer: SCD AF (5'-GAAACTTCCCCAGTGCC-3') and SCD AR (5'-CAAGTGGGCCGGCATC-3'), according to Pauciullo et al. (2010). Product specificity was confirmed by ethidium-bromide-stained $1.5 \%$ agarose gel electrophoresis.

The entire panel of 322 animals was genotyped for the g.133A > C SNP using a PCR-RFLP method. Digestion of $17 \mu \mathrm{l}$ of each PCR amplification was accomplished with $10 \cup$ of $T a q l$ endonuclease (T\CGA) (Promega) for $5 \mathrm{~h}$ at $65{ }^{\circ} \mathrm{C}$. The digestion products were analysed directly by electrophoresis in $1.5 \%$ agarose gel in $1 \mathrm{X}$ TBE buffer and stained with ethidium bromide.

\section{Phenotypic data collection}

For a subsample of 169 buffalo cows an association study between the SNP polymorphism and milk yield was carried out. A total of 43510 test-day (TD) records for milk yield measured daily with an automatized milk recording system on 226 lactations of 169 Italian water buffalo cows of different parities (1-7) were used. Data were collected in the period January 2007-September 2009 in a herd located in the province of Salerno. Animals were milked twice a day with the Afifarm system (S.A.E. Afikim, Kibbutz Afikim, Israel).

\section{Bioinformatic and statistical analysis}

The allele frequency and Hardy-Weinberg equilibrium $\left(\chi^{2}\right.$ test) were calculated for the larger sample of 322 buffaloes. Homology searches, comparison among sequences, and multiple alignments were accomplished using DNAsis-Pro (Hitachi), whereas the putative transcription factor binding sites were searched by Transfact ${ }^{\circledR} 7.0$ software.

Associations between SCD polymorphism for 169 buffaloes and milk yield was investigated with the following mixed linear model (SAS Institute, Cary NC, USA):

$$
\begin{aligned}
y_{i j l m n}= & \mathrm{YS}_{i}+\operatorname{Par}_{j}+\mathrm{SCD}_{l}+\operatorname{DIM}_{m}+\operatorname{DIM}_{m}\left(\mathrm{SCD}_{l}\right) \\
& +c_{n}\left(\mathrm{SCD}_{l}\right)+e_{i j l m n}
\end{aligned}
$$

where $y_{i j / m n}=$ test-day record of milk yield; $Y S=$ fixed effect of the ith year per season of production (8 levels: autumn 2007 to summer 2009); Par=fixed effect of the $j$ th parity (5 levels: $1-4,>5)$; SCD =fixed effect of the /th SCD genotype (3 levels: AA, AC, CC); DIM=fixed effect of the $m$ th stage of lactation (30 levels of $10 \mathrm{~d}$ each); $c=$ random effects of individual cow (169 levels), nested within SCD genotype; $e_{i j / m n}=$ random residual.

The fixed effect of SNP genotype fits the average effect across the whole lactation. The DIM (days in milk) factor nested within SCD genotype was included in the model to estimate lactation curves of the different genotypes (Stanton et al. 1992). (Co)variance matrices of random effects of cow and residual were assumed to be diagonal, $\mathbf{I} \sigma^{2} \mathrm{C}$ and $\mathbf{I} \sigma^{2} \mathrm{e}$, respectively. They allow for the REML estimation of variance components associated to individual $\operatorname{cow}\left(\sigma_{\mathrm{c}}^{2}\right)$ and residual $\left(\sigma_{\mathrm{e}}^{2}\right)$. Statistical significance of the SNP effect was tested against variance of cow nested within SNP genotype 


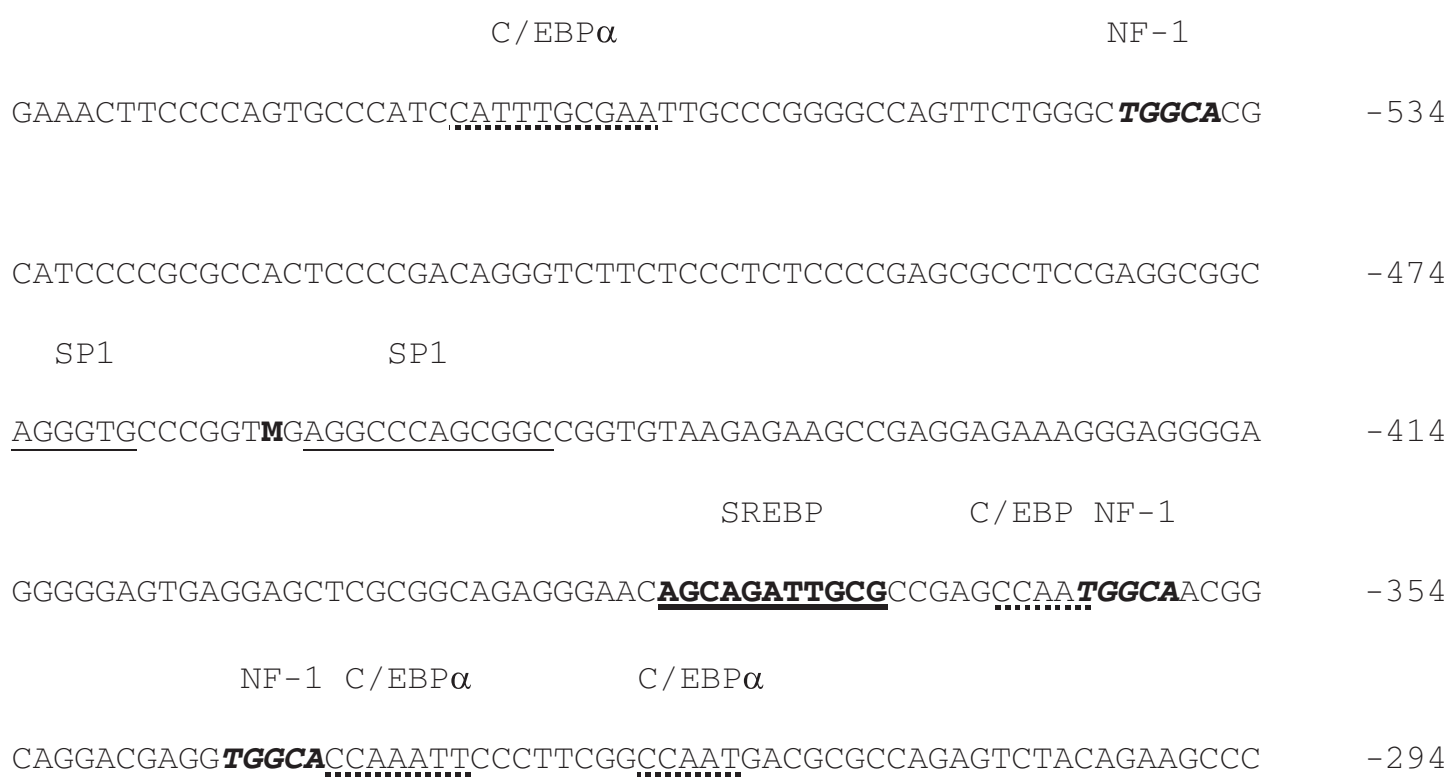
$\mathrm{C} / \mathrm{EBP} \beta$
$\mathrm{C} / \mathrm{EBP} \alpha$
$\mathrm{C} / \mathrm{EBP} \alpha$

ATTAGCATTTCCCCAGGGGCAGGGGCAGAGGCAGGGGCTGCGGCGGCTAAGCCGCGGTGT

$\mathrm{C} / \mathrm{EBP} \alpha$

GTCTGCAGCATCCAGTTCTTECTTCTTCGGCCCCCAGCACGCCTCGGCGCTCTGTCTCCT

CCCCTCTCCCGCCCATGCGGATCTCCCACGGTGAGCCAACTCTGCGCACTTTGCCCCTTG

$$
\mathrm{NF}-1
$$

TATA box

$\mathrm{C} / \mathrm{EBP} \alpha$

SREBP

SP1

TTGGCAACGAATAAAAGGGGTCTGAGGAAATACGGGACACAGTCACCCCCTGCCAGCGCT

TATA BOX

PPAR $\gamma$

SP1

ATTAAATCCCCAGCACAGCAGGTCGGGTCCGGACACCGGTCCAGCGCGCACCG tgcagCg

PPAR $\gamma$

gaaggtcccgagcgcagcgccgcggatcgccacgcaaaagcaggctcaggaactagtcta

Fig. 1. Key transcription factors binding sites found in the $5^{\prime}$ promoter region of the river buffalo SCD gene. The conserved polyunsaturated fatty acid (PUFA) response region including the sterol response element (SREBP), CCAAT-box (C/EBP), nuclear factor (NF)-1 and stimulator protein 1 (SP1) binding site are shown. TATA motifs and peroxisome proliferator activated receptor- $\gamma$ (PPAR- $\gamma$ ) are also shown proximal to the transcription start site. SNP g.133A $>$ C is indicated with M nucleotide according to international nomenclature

(Littell et al. 1998). Pairwise comparisons among different levels of fixed effects included in model were performed using a Bonferroni adjusted test.

The average gene substitution effect $(\alpha)$ was calculated using a mixed linear model with the same structure of (1) but with the gene effect treated as a covariable, represented by the number of $C$ alleles at the SCD locus $(0,1,2)$, and an interaction between alleles at the SNP locus to account for possible dominance effects (Banos et al. 2008).

Finally, in order to estimate the contribution of the SCD locus to the variance of the trait, a mixed model having the same structure of (1) but with the SCD genotype treated as random was run. Thus a variance component associated to the SCD locus $\left(\sigma_{S C D}^{2}\right)$ was estimated. Contributions of SCD 


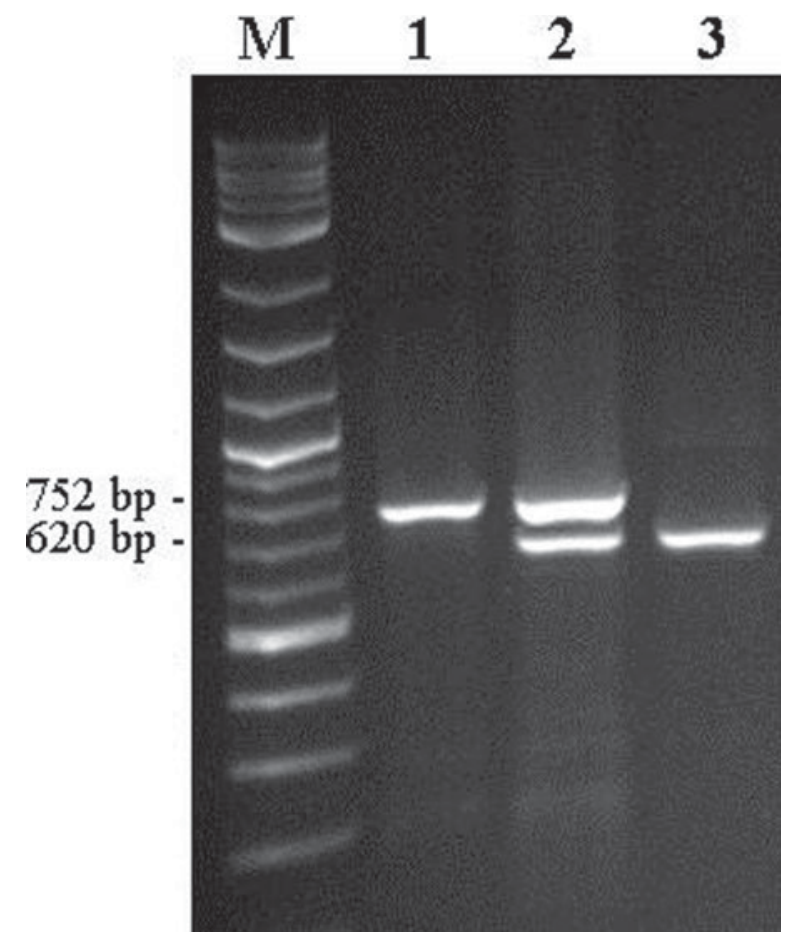

Fig. 2. Genotyping of SCD g.133A > C SNP by Taq I (T\CGA) PCRRFLP. Line 1: AA homozygous samples; line 3: CC homozygous samples; line 2 heterozygous samples. In the lines 2 and 3 is not visible the band 132 bp long. Line $M$ is $2-\log$ DNA ladder $(0 \cdot 1-10 \mathrm{~kb}$; New England Biolabs)

locus $\left(r_{\mathrm{SCD}}^{2}\right)$ and cow $\left(r_{\mathrm{C}}^{2}\right)$ to the total phenotypic variance of the trait considered were calculated as:

$r_{\mathrm{SCD}}^{2}=\frac{\sigma_{\mathrm{SCD}}^{2}}{\sigma_{\mathrm{SCD}}^{2}+\sigma_{\mathrm{C}}^{2}+\sigma_{\mathrm{e}}^{2}} \quad$ and $\quad r_{\mathrm{C}}^{2}=\frac{\sigma_{\mathrm{C}}^{2}}{\sigma_{\mathrm{C}}^{2}+\sigma_{\mathrm{e}}^{2}+\sigma_{\mathrm{SCD}}^{2}}$

\section{Results and Discussion}

\section{Characterization of river buffalo SCD promoter}

A total of $593 \mathrm{bp}$ of the river buffalo $S C D$ promoter (EMBL acc. no. FM876222) upstream the first nucleotide of the first exon were analysed by using Transfact $^{\circledR} 7.0$ software and characterized in order to investigate the putative transcription factor binding sites that could regulate the gene expression (Fig. 1).

The buffalo SCD promoter contains two TATA box located, with reference to the first nucleotide of the first exon, at nucleotides $-51 /-48$ and $-102 /-99$ and at least four SP1 consensus sequence $(-473 /-468,-459 / 448$, $-58 / 64,-18 /-6)$. The high GC content $(64.9 \%)$ is a typical feature of housekeeping genes promoters (Zhu et al. 2008) and the presence of these last sites could contribute to the constitutive expression of the $S C D$ in various tissues.

Several CCAAT/enhancer binding protein (C/EBP) were identified. This family of transcription factors are key regulators of adipogenesis and lipid metabolism, playing a fundamental role in expression of adipocyte genes as ADIPOQ, DGAT1, LPL, CD36 (Olofsson et al. 2008). In river buffalo $S C D$ promoter, most of these C/EBP consensus sequences were found in a very closed DNA fragment of about 130 bp (nucleotide $-382 /-250$ ), suggesting that this region could have an essential function in the gene expression. To support these findings, a multiple sequence alignment of the river buffalo, pig, human and mouse $S C D-1 / S C D-2$ promoters was achieved (data not shown). Such DNA region was found to be highly conserved and among the found binding sites for transcription factors, those regulating lipid metabolism were: one sterol regulatory element binding protein (SREBP) at position $-382 /-372$, which is considered a key components of trans-10, cis-12 C18:2 conjugated linoleic acid (CLA) regulation of bovine milk fat synthesis (Harvatine \& Bauman, 2006); and two nuclear factor (NF)-1 binding sites (-362/-358 and $-343 /-339$ ), which are functional enhancers with specificity for adipose cells and involved in adipocyte-specific gene expression (Graves et al. 1991).

The analysis of the remaining portion of 5 ' flanking region showed other regulatory elements: one sterol regulatory element (SREBP) at the nucleotides $-71 /-68$, one NF-1 at the position $-112 /-108$ and two peroxisome proliferator activated receptor- $\gamma$ (PPAR- $\gamma$ ) at the positions $-34 /-29$ and $10 / 15$. PPAR- $\gamma$ is often referred as the 'master regulator' of adipogenesis because it participates in the transcriptional activation of numerous adipogenic and lipogenic genes (Paton \& Ntambi, 2009). Recently, a gene network analysis in bovine mammary tissue showed that expression of PPAR- $\gamma$ and its putative target genes was up-regulated during lactation, suggesting a role for this nuclear receptor in the regulation of milk fat synthesis (Bionaz \& Loor, 2008).

\section{Genotyping}

The transvertion g.133A $>C$ creates a restriction site for the endonuclease Taql, thus a PCR-RFLP protocol was set up for the quick genotyping of the samples. Digestion of the PCR product $(752 \mathrm{bp}$ ) allows the identification of both alleles (Fig. 2).

The restriction pattern is characterized by one undigested fragment of $752 \mathrm{bp}$ for the AA homozygous samples, whereas the same amplicon is restricted into two fragments of 132 and $620 \mathrm{bp}$ in the presence of cytosine at the homozygous status. The restriction pattern of the heterozygous samples shows 3 fragments. The frequency of cytosine in the sample of 322 buffaloes was $0 \cdot 16$ (Table 1). This value might open the possibility for a rapid directional selection in favour of the $\mathrm{C}$ allele, which was found to be associated with a higher content of unsaturated FAs in milk (Pauciullo et al. 2010). Hardy-Weinberg disequilibrium was detected for the genotype distribution, but this event could be the result of several causes. In particular, the restricted number of genotyped individuals and the mating system. In the last case, even though the mating technique in buffalo is still almost exclusively natural for the physiological 
Table 2. Least squares means of milk yield $(\mathrm{kg} / \mathrm{d})$ for the three genotypes at the g.133A >C SNP in the promoter of SCD gene estimated with model (1)

$\begin{array}{lcc}\text { SCD genotype } & \text { Milk yield }(\mathrm{kg} / \mathrm{d}) & \text { SE } \\ \text { AA } & 8 \cdot 63^{\mathrm{ab}} & 0 \cdot 20 \\ \text { CA } & 8 \cdot 83^{\mathrm{a}} & 0 \cdot 33 \\ \text { CC } & 6 \cdot 60^{\mathrm{b}} & 0 \cdot 73 \\ \text { a,b } & \\ \text { adjusted } P<0 \cdot 05) & \end{array}$

problems in the application of the AI (Barile, 2005; Drost, 2007), we cannot exclude an inbreeding effect often due to the use of the same tested bulls.

\section{Association between SCD genotype and milk traits}

The $S C D$ genotype was significantly associated with milk yield $(P=0.02)$ (Table 2). In particular, buffalo cows with heterozygous genotype AC at the promoter of SCD locus showed the highest daily milk yield, with more than $2 \mathrm{~kg} / \mathrm{d}$ compared with CC buffaloes. Such a difference accounts for about $28 \%$ more milk per day. On the contrary homozygous AA were slightly lower than AC. The behaviour of the three genotypes tended to remain constant throughout the whole lactation, as can be seen from the estimated lactation curves of the three genotypes (Fig. 3). A similar pattern has been observed also in other association studies involving polymorphisms at the $S C D$ gene in Italian Holstein (Macciotta et al. 2008) and at the OXT gene in river buffalo (Pauciullo et al. 2011).

The allele substitution effect of the adenine into cytosine was about $-1 \mathrm{~kg} / \mathrm{d}(P<0 \cdot 01)$, and the contribution of the $S C D$ polymorphism to the total phenotypic variance was $12 \%$ (Table 3). Such an effect is larger than the one reported for the SCD (Macciotta et al. 2008) and also higher than the contribution reported for DGAT1 (Grisart et al. 2002) on milk yield in dairy cattle.

The large effect of dominance on milk yield observed in the present work, more than $1.2 \mathrm{~kg}(P<0 \cdot 02)$, is also very interesting (Table 3 ). This offers a possible explanation of the over-dominance effect of the heterozygous (AC) on the best homozygous phenotype (AA). Often such an effect is not detected or considered to be not relevant because numerically much lower than the additive effect. However, it might have an impact on allele substitution effect in the population as recently reported in dairy cattle (Kuehn et al. 2007). Moreover, lactation curves of different genotypes showed that the superiority of the heterozygous over the AA genotype is concentrated mainly around the lactation peak and, to a lesser extent, between 120 and 150 DIM (Fig. 3).

In previous research carried out on the same group of animals, Pauciullo et al. (2010) showed that CC genotype is associated to higher desaturation index in milk fatty acids, probably as consequence of an additional SP1 transcription factor in the promoter. It is also well known that the lipid 
Table 3. Mean \pm SE of milk yield $(\mathrm{kg} / \mathrm{d})$ for the substitution effect g. $133 \mathrm{~A}>\mathrm{C}$ in the promoter region of the river buffalo SCD gene and contribution of this polymorphism to the phenotypic variance

\begin{tabular}{|c|c|c|c|c|c|c|c|c|c|}
\hline Trait & $\alpha+$ & $P$ & $d \neq$ & $P$ & $\sigma_{\mathrm{SCD}}^{2} \S$ & $\sigma_{\mathrm{c}}^{2}$ & $\sigma_{\mathrm{e}}^{2}$ & $r_{\mathrm{c}}^{2} \boldsymbol{\Phi}$ & $r_{\mathrm{SCD}}^{2}$ \\
\hline Milk yield & $-1 \cdot 01 \pm 0 \cdot 38$ & $0 \cdot 007$ & $1 \cdot 22 \pm 0 \cdot 49$ & $0 \cdot 013$ & 0.93 & $4 \cdot 21$ & $2 \cdot 72$ & $0 \cdot 61$ & $0 \cdot 12$ \\
\hline
\end{tabular}

$+\alpha$ : Substitution effect

$\neq \mathrm{d}$ : dominance effect

$\S \sigma^{2}$ : variance components associated to the genotype (SCD); to the individual buffalo cow (c), to residuals (e)

I $r^{2}$ : contributions of genotype (SCD) and of individual buffalo cow (c) to the total phenotypic variance

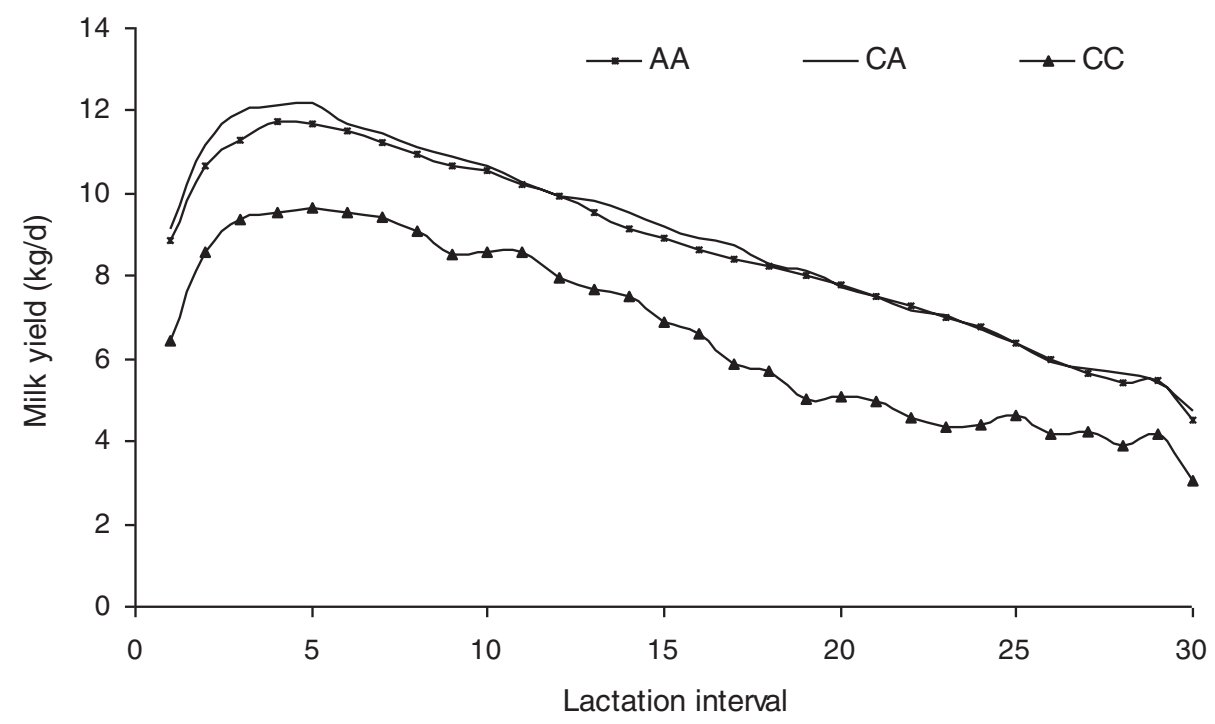

Fig. 3. Lactation curves of different SCD genotype for milk yield $(\mathrm{kg} / \mathrm{d})$

Table 4. Least squares means of milk yield $(\mathrm{kg} / \mathrm{d})$ for the different levels of parity estimated with model (1)

$\begin{array}{lccl}\text { Effect } & \text { Level } & \text { Milk yield }(\mathrm{kg} / \mathrm{d}) & \mathrm{SE} \\ \text { Parity } & 1 & 6 \cdot 04^{\mathrm{A}} & 0 \cdot 30 \\ & 2 & 6 \cdot 87^{\mathrm{B}} & 0 \cdot 29 \\ & 3 & 9 \cdot 24^{\mathrm{C}} & 0 \cdot 30 \\ & 4 & 10 \cdot 55^{\mathrm{D}} & 0 \cdot 34 \\ & 7 & 7 \cdot 41^{\mathrm{B}} & 0 \cdot 48 \\ \mathrm{~A}, \mathrm{~B}, \mathrm{C}, \mathrm{D} \text { Means within columns with different superscripts differ }(P<0 \cdot 01)\end{array}$

metabolism and the de-novo biosynthesis of fatty acids are complex pathways and they are energetically very expensive. As suggested for dairy cattle (Kay et al. 2005; Macciotta et al. 2008), in cows with greater desaturase activity, fewer nutrients are directed toward milk yield. In river buffalo, the CC genotype at SCD locus showed an increased $\triangle 9$ desaturase activity and higher milk monounsaturated FA content (Pauciullo et al. 2010), but it is also characterized by lower milk yield. Therefore, our findings would seem to confirm this relationship.

\section{Environmental factors affecting milk traits}

Parity and year $\times$ calving season significantly affected buffalo daily milk yield (Table 4). Milk production tended to increase from first to later parities, reaching the maximum at the fourth calving. These findings are in agreement with previous reports on buffaloes (Catillo et al. 2002; Dang et al. 2010). Across all years, highest daily milk yields were observed for buffaloes calving in autumn whereas lowest values were for summer calvings (not reported for brevity). The seasonal effects on productive performances of buffaloes are not news. As reported in Mediterranean and Pakistan Nili-Ravi breed (Catillo et al. 2002; Afzal et al. 2007), a depressive effect of high temperatures at the beginning of the lactation is recorded for calving in summer.

\section{Conclusions}

Stearoyl-CoA desaturase genes have been intensively investigated in ruminants mainly through association studies between SNP and the fatty acid spectrum. This study reports an association between the g.133A >C SNP previously found in the promoter region of $S C D$ gene and daily milk yield in the Italian river buffalo.

Little information is available for this species about association studies but also on the effectiveness of traditional selection schemes. On the other hand, much work has been done to improve recording, health, feeding and livestock systems. 
This study represents one of the first indications of an association between a trait of economic importance and a candidate locus in river buffalo. A full characterization of the $S C D$ promoter region was proposed, genotyping information for the SNP g.133A > C was provided and a quick method for allelic discrimination was set up. A significant association with daily milk yield has been found at SCD gene. The genotype AC showed an over-dominance effect with an average daily milk yield approximately $1 \cdot 2 \mathrm{~kg} / \mathrm{d}$ higher. The effect of the genotype was constant across lactation stages. Although such results need to be confirmed with large-scale studies in the same and other buffalo populations, they might be of great economic interest for the buffalo dairy industry.

This work was financially supported by the Italian Ministry for Agriculture and Forestry Policy—MiPAAF (INNOVAGEN project).

\section{References}

Afzal M, Anwar M \& Mirza MA 2007 Some factors affecting milk yield and lactation length in Nili-Ravi buffaloes. Pakistan Veterinary Journal 27 113-117

AIA 2010 Milk recording activity: official statistics. In Annual Report of the Italian Breeders Association. p. 31. Rome, Italy: Associazione Italiana Allevatori

Banos G, Woolliams JA, Woodward BW, Forbes AB \& Coffey MP 2008 Impact of single nucleotide polymorphisms in leptin, leptin receptor, growth hormone receptor, and diacylglycerol acyltransferase (DGAT1) gene loci on milk production, feed, and body energy traits of UK dairy cows. Journal of Dairy Science 91 3190-3200

Barile VL 2005 Improving reproductive efficiency in female buffaloes. Livestock Production Science 92 183-194

Bionaz M \& Loor JJ 2008 Gene networks driving bovine milk fat synthesis during the lactation cycle. BMC Genomics 9366

Borghese A \& Mazzi M 2005 Buffalo population and strategies in the world. In Buffalo Production and Research, pp. 1-40. Roma, Italy: FAO Regional Office for Europe

Carta A, Casu S, Usai MG, Addis M, Fiori M, Fraghı A, Miari S, Mura L, Piredda G, Schibler L, Sechi T, Elsen JM \& Barillet F 2008 Investigating the genetic component of fatty acid content in sheep milk. Small Ruminant Research 79 22-28

Catillo G, Macciotta NPP, Carretta A \& Cappio-Borlino A 2002 Effects of age and calving season on lactation curves of milk production traits in Italian water buffaloes. Journal of Dairy Science 85 1298-1306

Dang AK, Mukherjee J, Kapila S, Mohanty AK, Kapila R \& Prasad S 2010 In vitro phagocytic activity of milk neutrophils during lactation cycle in Murrah buffaloes of different parity. Journal of Animal Physiology and Animal Nutrition 94 706-711

Drost M 2007 Advanced reproductive technology in the water buffalo. Theriogenology 68 450-453

García-Fernández M, Gutiérrez-Gil B, García-Gámez E, Sánchez JP \& Arranz JJ 2010 Detection of quantitative trait loci affecting the milk fatty acid profile on sheep chromosome 22: role of the stearoyl-CoA desaturase gene in Spanish Churra sheep. Journal of Dairy Science $\mathbf{9 3}$ 348-357

Gautier M, Barcelona RR, Fritz S, Grohs C, Druet T, Boichard D, Eggen A \& Meuwissen THE 2006 Fine mapping and physical characterization of two linked quantitative trait loci affecting milk fat yield on BTA26. Genetics $172425-436$
Gossens M \& Kan JW 1981 DNA analysis in the diagnosis of haemoglobin disorders. Methods in Enzymology 76 805-817

Graves RA, Tontonoz P, Ross SR \& Spiegelman BM 1991 Identification of a potent adipocyte-specific enhancer: involvement of an NF-1-like factor. Genes and Development 5 428-437

Grisart B, Coppieters W, Farnir F, Karim L, Ford C, Berzi P, Cambisano N, Mni M, Reid S, Simon P, Spelman R, Georges M \& Snell R 2002 Positional candidate cloning of a QTL in dairy cattle: identification of a missense mutation in the bovine DGAT1 gene with major effect on milk yield and composition. Genome Research 12 222-231

Harvatine KJ \& Bauman DE 2006 SREBP1 and thyroid hormone responsive spot 14 (S14) are involved in the regulation of bovine mammary lipid synthesis during diet-induced milk fat depression and treatment with CLA. Journal of Nutrition 136 2468-2474

Kay JK, Weber WJ, Moore CE, Bauman DE, Hansen LB, Chester-Jones $\mathbf{H}_{\text {, }}$ Crooker BA \& Baumgard LH 2005 Effect of week of lactation and genetic selection for milk yield on milk fatty acid composition in Holstein cows. Journal of Dairy Science 88 3886-3893

Kuehn C, Edel C, Weikard R \& Thaller G 2007 Dominance and parent-oforigin effects of coding and non-coding alleles at the acylCoAdiacylglycerol-acyltransferase (DGAT1) gene on milk production traits in German Holstein cows. BMC Genetics 2462

Littell RC, Henry PR \& Ammerman CB 1998 Statistical analysis of repeated measures data using SAS procedures. Journal of Animal Science $\mathbf{7 6} 1216$ 1231

Macciotta NPP, Mele M, Conte G, Serra A, Cassandro M, Dal Zotto R, Cappio Borlino A, Pagnacco G \& Secchiari P 2008 Association between a polymorphism at the stearoyl CoA desaturase locus and milk production traits in Italian Holsteins. Journal of Dairy Science 913184 3189

Mele M, Conte G, Castiglioni B, Chessa S, Macciotta NP, Serra A, Buccioni A, Pagnacco G \& Secchiari P 2007 Stearoyl-coenzyme A desaturase gene polymorphism and milk fatty acid composition in Italian Holsteins. Journal of Dairy Science $\mathbf{9 0}$ 4458-4465

Moioli B, Contarini G, Avalli A, Catillo G, Orru L, De Matteis G, Masoero G \& Napolitano F 2007 Effect of stearoyl-coenzyme A desaturase polymorphism on fatty acid composition of milk. Journal of Dairy Science 90 3553-3558

Ntambi JM 1999 Regulation of stearoyl-CoA desaturase by polyunsaturated fatty acids and cholesterol. Journal of Lipid Research $\mathbf{4 0}$ 1549-1558

Olofsson LE, Orho-Melander M, William-Olsson L, Sjöholm K, Sjöström L, Groop L, Carlsson B, Carlsson LM \& Olsson B 2008 CCAAT/enhancer binding protein $\alpha(\mathrm{C} / \mathrm{EBP} \alpha)$ in adipose tissue regulates genes in lipid and glucose metabolism and a genetic variation in C/EBP $\alpha$ is associated with serum levels of triglycerides. Journal of Clinical Endocrinology and Metabolism 93 4880-4886

Paton CM \& Ntambi JM 2009 Biochemical and physiological function of stearoyl-CoA desaturase. American Journal of Physiology Endocrinology and Metabolism 297 E28-E37

Pauciullo A, Cosenza G, D'Avino A, Colimoro L, Nicodemo D, Coletta A, Feligini M, Marchitelli C, Di Berardino D \& Ramunno L 2010 Sequence analysis and genetic variability of stearoyl CoA desaturase $(S C D)$ gene in the Italian Mediterranean river buffalo. Molecular and Cellular Probes $\mathbf{2 4}$ 407-410

Pauciullo A, Cosenza G, Steri R, Coletta A, Jemma L, Feligini M, Di Berardino D, Macciotta NPP \& Ramunno L 2011 An association analysis between OXT genotype and milk yield and flow in Italian Mediterranean river buffalo. Journal of Dairy Research 79 150-156

Stanton TL, Jones LR, Everett RW \& Kachman SD 1992 Estimating milk, fat, and protein lactation curves with a test day model. Journal of Dairy Science 75 1691-1700

Zhu J, He F, Hu S \& Yu J 2008 On the nature of human housekeeping genes. Trends in Genetics 24 481-484 